\title{
CHARACTERISTIC PROPERTIS OF MORPHOLOGY AND FORMATION OF COMMERCIAL COAL SEAMS OF DEEP HORIZONS OF THE LVIV-VOLYN COAL BASIN
}

\author{
Mykhailo Matrofailo ${ }^{1}$ \\ Mykola Korol ${ }^{2}$
}

DOI: https://doi.org/10.30525/978-9934-588-15-0-144

\begin{abstract}
The Lviv-Volyn Coal Basin remains being the main fuel-power base of the western regions of the Ukraine up to now. At the same time, against the background of the planned removing of mines from service and reduction of explored reserves of coal, the necessity arises to solve the question of the basin's development in the future. Its up-to-date expansion is also connected with the development of the coal seams trom the deep horizons. We have studied the commercial coal potential and characteristic properties of morphology of the coal seams of the deep horizons of the Lviv-Volyn Coal Basin, including the Kovel coal-bearing area. To the deep horizons we attribute the parts of the section of the Carboniferous thickness that enclose the coal seams located at depths below the working coal seams. They are of Tournaisian-Serpukhovian age and belong to the lower (bog-marine) coal-bearing formation. The purpose of investigations was to determine the most perspective commercial coal seams of the deep horizons of the basin and their characteristic properties. It was noted that within the limits of the workable deep horizons of the basin the coal seams $v_{0}{ }^{3}$ and $v_{6}$ are widely distributed. We have used a complex of investigations based on the formation analysis: morphological analysis of coal seams, methods of mapping and geological-industrial typification of the main morphological parameters of coal seams, correlation, paleopothamic and lithological-stratigraphical analyses, construction of detailed morphologi-
\end{abstract}

\footnotetext{
${ }^{1}$ Candidate of Geology and Mineralogy, Senior Research Fellow, Senior Scientific Worker of the Department of Geology and Geochemistry of Solid Combustible Minerals, Institute of Geology and Geochemistry of Combustible Minerals of the National Academy of Sciences of Ukraine, Ukraine

${ }^{2}$ Chief geologist, Separated Subdivision "Geological Research Expedition" of the State Enterprise "Lvivvuhillya", Ukraine
} 
cal sections, genetic and paleotectonic analyses of Carboniferous deposits. Results of studies have enabled us to determine characteristic properties of the formation and morphology, in particular splitting, of the Visean $v_{0}{ }^{3}$ and Serpukhovian $v_{6}$ coal seams. Maps of morphology $v_{0}{ }^{3}$ (scale $1: 50000$ ) and $v_{6}$ (scale $1: 25000$ ) have been compiled that reflected morphostructural and morphogenetic features, a commercial value and changes in their main mining-geological factors and phenomena in the basin area. It was established that accumulation of initial organic material of the seam $v_{0}{ }^{3}$ in the Kovel coal-bearing area depends on inherited tectonic valley-like lowering of the latitudinal strike. For the first time for the basin there was determined a new type of the peat accumulation characteristic of the platform Carboniferous coal-bearing formations located directly on the erosional surface of Pre-Carboniferous formations of different age. It was ascertained that the coal seam $v_{6}$ was formed within the limits of the subaerial deltal plain where the most favourable conditions for accumulation of the peat bogs existed in the pre-channel parts of delta located in the interchannel space among and under the influence of the large paleohydrographical systems. For the first time for this seam, the deltaic type of the peat accumulation was determined. Thus, within the limits of the deep horizons in deposits of the lower coal-bearing sub formation the coal seams $v_{0}{ }^{3}$ and $v_{6}$ are the main and have the most commercial value. In the Kovel perspective area and the central part of the basin: $v_{0}{ }^{3}$ and $v_{6}-$ in Zabuske and Mezhyrichchia fields of the Chervonohrad coal production region of the basin. Stated material and executed paleoreconstructions verify and supplement the existing notions of Carboniferous coal accumulation in the south-west of the East-European platform and of the little-studied deltaic type of the peat accumulation. In the light of applied aspect, they are important for solving of practical tasks connected with predicting evaluation of the commercial coal-bearing potential of the deep horizons of the Lviv-Volyn Basin.

\section{Introduction}

The Lviv-Volyn Coal Basin (LVB) (Figure 1) remains being the main fuel-power base of western region of the Ukraine up to now. However, against the background of the planned removing of mines from service and reduction of explored reserves of coal, the necessity arises to solve the question of the basin's development in the future. 
In the Lviv-Volyn Coal Basin, the highest potential for coal presence of commercial value falls to deposits of the Buzhanka suite. Eight basic commercial coal seams $n_{7}{ }^{\text {}}\left(n_{7}\right), n_{7}\left(n_{7}{ }^{1}\right), n_{7}{ }^{\mathrm{B}}, n_{8}, n_{8}{ }^{0}, n_{8}{ }^{\mathrm{B}}, n_{8}{ }^{5}$ and $n_{9}$ (in brackets is indicated synonimics of coal seams accepted in the South-Western coal-bearing region of LVB) have the working thickness at rather great areas $[3 ; 19-21]$. At the same time, of great importance are studies, prediction and mapping of morphology of the coal seams with the working thickness that occur below at deeper horizons $[10 ; 20]$.

To deep horizons belong those parts of the section of the coal-bearing thickness of LVB that contain coal seams located at great depths below working seams. They are Tournaisian-Serpukhovian in age, and belong to the lower (marshy-marine) coal-bearing formation. As results of researches have shown, within the limits of deep horizons of the basin the coal seams $v_{0}{ }^{3}, v_{0}{ }^{4}, v_{2}, v_{4}, v_{4}{ }^{3}, v_{5}{ }^{4}, v_{5}{ }^{6}, v_{6}, n_{0}{ }^{6}$ with working thickness are widely distributed. To such parts of the section one can attribute the northern continuation of the basin: the Kovel perspective area, the region of Carboniferous spreading along the Poland border from the town of Volodymyr-Volynskiy to the Belarus border where the coal seam $v_{0}{ }^{3}$ occurs. It stretches as a strip, from 15 to $20 \mathrm{~km}$ wide, at a distance of about 100 kilometres along the state border. Its area is estimated at a total of $420 \mathrm{~km}^{2}$. On the whole in deposits of the lower coal-bearing subformation, $v_{0}{ }^{3}$ and $v_{6}$ are basic seams that preserve working thickness at considerable areas.

Studying of coal seams situated within undeveloped territories and active mines of the basin, at horizons that are deeper than working ones and substantiation of their commercial value for duration of operating period of mines is an urgent problem that needs to be solved. Commercial working of such seams is a perspective direction of further development of LVB and coal industry of the western region of the Ukraine.

Basing on paleoreconstructions, paleopothamic and morphological analyses and detailed studies of the structure, discomposition and washout of coal seams $v_{0}{ }^{3}$ and $v_{6}$ as well as of changes in these parameters and phenomena along the area, it was possible to depict formation conditions of coal-bearing deposits and morphological features of seams indicated in the maps of morphology. 

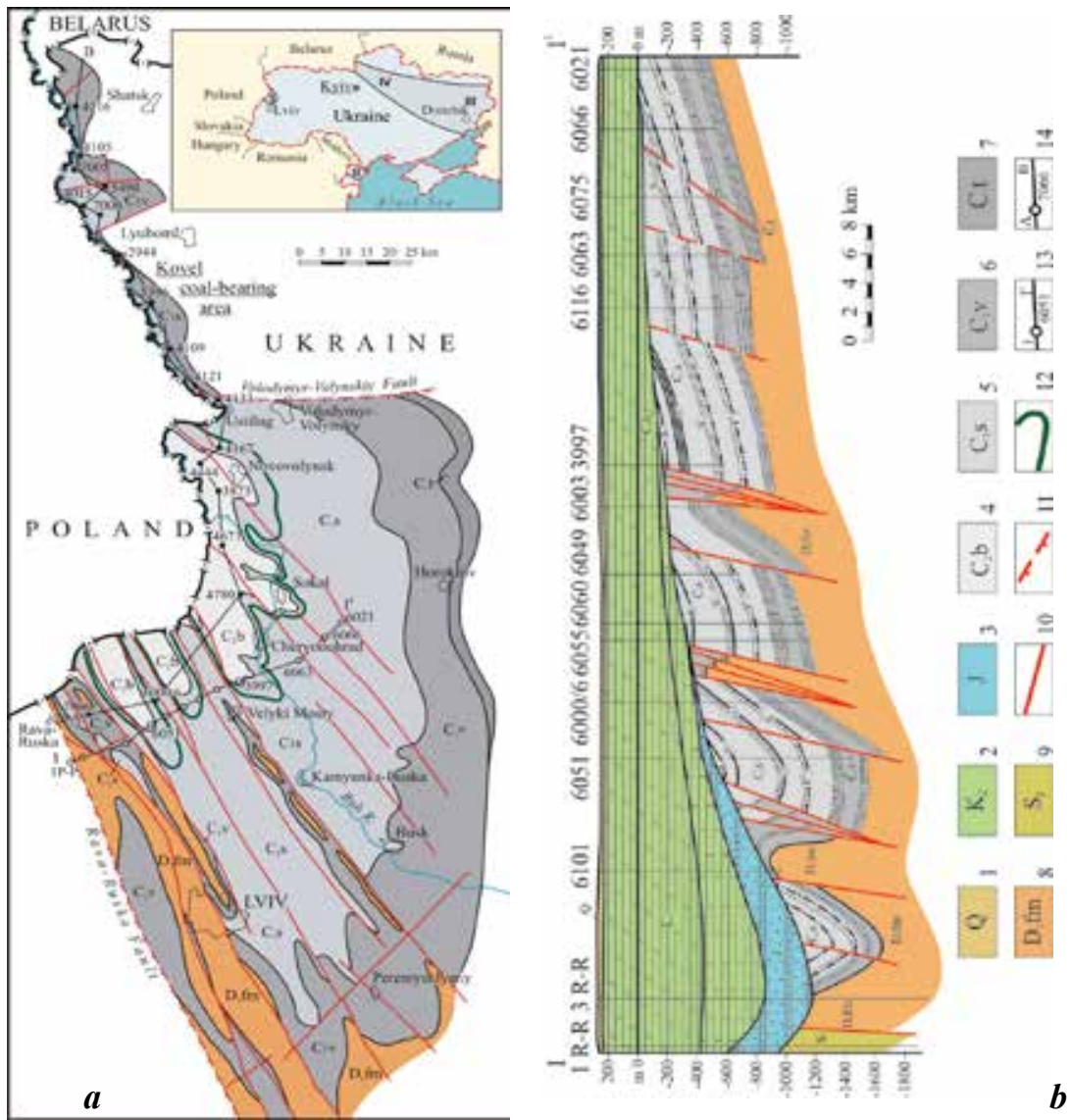

Figure 1. Geological map (a) and cross-section along the line $\mathbf{I}-\mathbf{I}^{1}$ (b) of the Lviv-Volyn Coal Basin (by Ihor Kostyk and Mykhailo Matrofailo, on the basis of materials of the Lviv GRE) [17]

1-3 - formation of Mesozoic and Cainozoic: 1 - Quarternary, 2 - Upper Cretaceous, 3 - Jurassic; 4-7 - Carboniferous period, middle section: 4 - Bashkirian stage, lower section: 5 - Serpukhovian stage, 6 - Visean stage, 7 - Tournaisian stage; 8 - Devonian, upper section, Famennian stage; 9 - Silurian, upper section; 10 - tectonic dislocations with a break of continuity; 11 - regional fault; 12 - contour of commercial coal presence; 13 - line of geological section and borehole number; 14 - line of correlational profile. Location of carboniferous basins and coal-bearing areas (on cutting): basins: I - Lviv-Volyn, II - Predobrogean, III - Donets, IV - Dnieper-Donets area 


\section{Methods of investigations}

To study morphostructural and morphogenetic features of coal seams $v_{0}{ }^{3}$ and $v_{6}$ in details, changes in these parameters and phenomena over the area, correlation of coal-bearing deposits of the basin and regional cartographical representation of the results we have used the methods developed and applied for the basin near Moscow, Donets and Lviv-Volyn basins [15; 18; 19]. Moreover, we have used the methods of mapping (scale $1: 50000)$ and geological-commercial typification of main morphological parameters of coal seams, paleopothamic and lithological-stratigraphic analyses, construction of detailed morphological sections (scale: vertical $1: 200$, horizontal $1: 50000$ ). Maps of coalbed morphology show outlined and marked areas of the same type structure and traced boundaries of splitting, and washout as well as depicted development of coaly argillites. The isoline of the rock interbed $0.50 \mathrm{~m}$ thick is accepted as the outline of the splitting zone. A change in the thickness of the coal seams is represented by isopachytes drawn with line spacing of $0.20 \mathrm{~m}$, and the depth of occurrence of the rock bottom: by isohypses with line spacing of $50 \mathrm{~m}$.

To study geological structure, to correlate coal deposits and the morphology of coal seams and to estimate resources of the Kovel area we have used a complex of investigations based on formation analysis [20]. In addition, we have carried out lithological investigations of the section and have described lithological-facies characteristic of rocks as well as we have correlated deposits of the Lviv-Volyn basin and its northern continuation, have characterized coal-bearing potential of the thickness and have executed the morphological analysis of coal seams and genetic and paleotectonic analysis of deposits of Carboniferous.

In particular, to correlate coal seams we have constructed the correlational geological profile based on data of sections throughout the whole territory of the basin studied in detail (from the town of Rava Ruska in the south to the Belarus border in the north) (Figure 2). Correlation of the profile was conducted on the basis of methods developed with special features of the structure and formation conditions of coal deposits of LVB taken into account [19]. Incidentally we have used reliable, widely distributed marker horizons: 1 - limestone seam $\mathrm{V}_{1}$ of the Volodymyr suite with overlain marine argillites with numerous interbeds and lenses of siderite; 2 - the thickness of limestones that contain foraminifers of the Ustilug suite with interbeds of argillites and coal; 3 - thick seams of limestone containing Late Visean foraminifers (probably from the lower part of the Porytsk suite). 


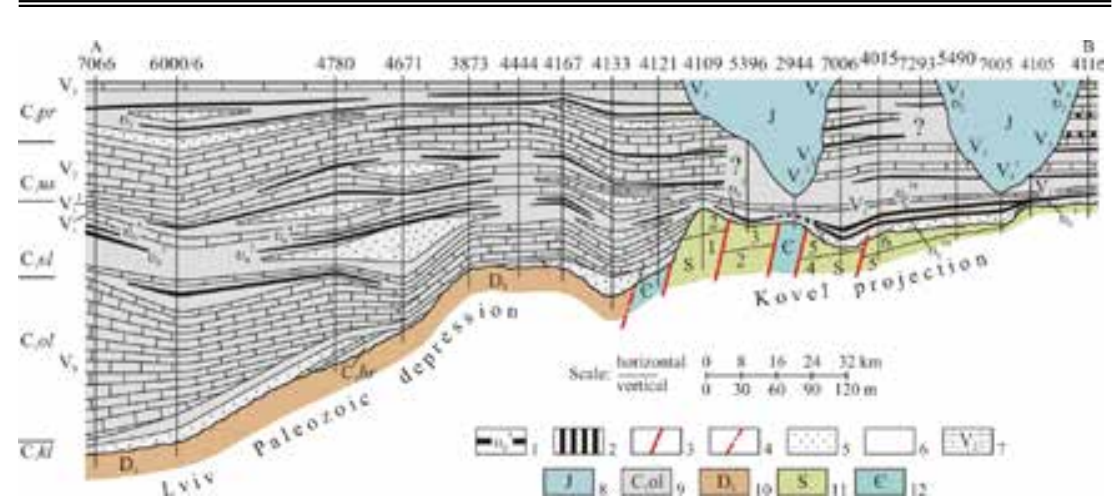

Figure 2. Correlational profile of the lower part of the coal-bearing formation of the Lviv-Volyn Coal Basin along the line A-B (line of section is indicated in Figure 1) [20]

1 - coal seam and its synonymics; 2 - coaly argillite; 3 - tectonic dislocations with a break of continuity; 4 - Volodymyr-Volynskiy (northern) fracture; 5 - sandstone; 6 - argillite; 7 - limestone and its synonymics; 8-12-deposits: 8 - Jurassic, 9 - Lower Carboniferous (suites: $\mathrm{C}_{1} k l$-Kulychkiv, $\mathrm{C}_{1} o l$-Oleska, , $\mathrm{C}_{1} v l$ - Volodymyr, $\mathrm{C}_{1} u s$ - Ustilug, $\mathrm{C}_{1} p r$ - Porytsk), 10 - Upper Devonian, 11 - Upper Silurian (graptolithic biozones (digits on profile): 1 - nilssoni chimaera, 2 - lentwardinensis, 3 - kozlowskii-auriculatus, 4 - formosus-spineus, 5 - ultimus-parultimus, 6 - lochkovensis); 12 -Cambrian

The geological commercial typification of coal seams was carried out in conformity with accepted gradations of classifications and standing instructions and methods with the aid of alphabetical-digital indexing of the main morphological indicators of the seam: thickness (I-IV), change in thickness $\left(\mathrm{M}_{1-2}\right)$, structure $\left(\mathrm{CT}_{1-4}\right)$, degree of distribution of washouts and substitutions $\left(\mathrm{P}_{1-4}\right)$.

\section{General description}

Structurally, the Kovel exploring perspective area is in the northern part of LVB situated within the Lviv Paleozoic Depression of the south-western margin of the East European Platform and is contiguous to the Volyn field. It should be also noted that it is extended within the limits the Kovel tectonic projection which is a part of the Kovel-Hrubeszów transverse uplift with distinctive high-amplitude fine-block tectonics. The formation of the projection is connected with maximum activity of horst-under- 
thrust dislocations in Pre-Visean time (Bretonian phase of Hercinian tectogenesis) [24]. This has caused, on the one hand, a wave-like character of the boundary-line of the distribution of Carboniferous, and on the other hand - subhorizontal occurrence of coal deposits on the deeply eroded surface of strongly dislocated rocks of the Lower Paleozoic. The depth of washing of the Pre-Carboniferous deposits in the limits of the Kovel projection reaches from 0.5 to $1.7 \mathrm{~km}$ [23].

Rocks of the Carboniferous system of the Kovel area occur uncomformably on washedout deposits of the Lower Paleozoic that differ in age, and they are represented by the Visean and Serpukhovian stages (Figure 3). The thickness of Carboniferous over an area does not exceed $224 \mathrm{~m}$. In the basement of the Carboniferous deposits of the area there occurred rocks of a crust of weathering - argillites, massive, yellow-grey in color, fat to the touch, with silky glitter, acute-angled crack, sometimes with vegetable remains, black and brown ferrous oölites. These rocks contain high concentrations of $\mathrm{Al}_{2} \mathrm{O}_{3}$ reaching up to 36.7-37.8 per cent. Argillites are similar to basal formations of Carboniferous in LVB (Kulychkiv suite) [1;2], as well as to "semikaolin" high-alumina kaolinite clays of the Lower Carboniferous of the basin near Moscow [7]. Within the territory studied argillites about $3 \mathrm{~m}$ thick are distributed locally and are very similar to those in the Kulychkiv suite of LVB that very likely indicates their development within the Kovel area.

Deposits of the Visean stage are mainly represented by rocks of Volodymyr and Ustilug suites. The Volodymyr suite is composed mainly of terrigenous rocks. In its bottom in the north-eastern part of the area there occurs thick series (about $20 \mathrm{~m}$ thick) of different-grained quartz sandstones with kaolin, rarely carbonate, cement with argillite interbeds and sometimes of kaolin clays. Above there occurs a series (from the first metres to 10 metres thick) of black coaly argillites among which the coal seam $v_{0}{ }^{3}$ is located and which is splitted into two conditional coal seams $v_{0}{ }^{3 \mathrm{H}}$ and $v_{0}{ }^{3 \mathrm{~B}}$ with which the total coal presence of the area is connected. Completion of the section is represented by deposits of grey argillites with interbeds of aleurolites and organogenous limestones, often with remains of corals and mollusks. Sometimes one can observe interbeds of conglomerates of small thick (about $0.30-0.50 \mathrm{~m}$ ) in the suite series. The thickness of the suite reaches about $40 \mathrm{~m}$. It should be noted that the seam $v_{0}{ }^{3}$ is also distributed in the central part of LVB. 


\section{Morphology of coal seams}

Coal seam v $_{0}{ }^{3}$ is extended throughout the whole territory of the Kovel area: in the north - in the Shatsk area, in the central part - in the Lyuboml area, and in the south - in the Novyny area, it borders upon the the Volodymyr-Volynskiy fault. It consists of two coal seams $v_{0}{ }^{3 \mathrm{H}}$ and $v_{0}{ }^{3 \mathrm{~B}}$ that are of working thickness and are a short way off and both in the southern and the northern directions are connected into the single coal seam of complex structure. From the above-mentioned gradations of parameters and phenomena it was possible to characterize the morphology and the main morphological indications of coal seams for the separate plots of the Kovel area and to depict them in the map of morphology (Figure 5) and in the sections (Figure 6).

The lower coal seam $v_{0}{ }^{3 \mathrm{H}}$ occurs at depths ranging from 319.6 to $551.2 \mathrm{~m}$ and is distributed in all plots of the area. The cover of the seam is mainly composed of argillite, and the bottom: mudstone, siltstone and rarely sandstone. Its thickness changes from 0.10 to $2.17 \mathrm{~m}$ (borehole 7006 ) and corresponds to four types of gradation: I - very thin, II - thin, III - medium, IV - thick. In the Novyny and Lyuboml plots of the area it is conditional and varies from 0.59 to $2.17 \mathrm{~m}$. Somewhat further north, in the

Shatsk plot, the seam is of very thin unworkable thickness reaching $0.35 \mathrm{~m}$ (borehole 4105) and $0.30 \mathrm{~m}$ (borehole 4116). Changeability of the thickness is weak $\left(\mathrm{M}_{1}\right)$, and only in the western part of the Lyuboml plot it is strong and very strong $\left(\mathrm{M}_{2}\right)$. According to reserves classification, the seam belongs to uneven group. Its structure changes from simple $\left(\mathrm{CT}_{1}\right)$ to complex $\left(\mathrm{CT}_{3}\right)$. Without rock interbeds the seam extends in the Novyny, Shatsk plots and in the east of the Lyuboml one; with one and two rock interbeds from 0.10 to $0.38 \mathrm{~m}$ thick: in the western, the thickest part of the Lyuboml plot. Interbeds area represented mainly by argillites, sometimes by sandstones. Coaly argillite from 0.15 to $0.25 \mathrm{~m}$ thick in different cases occurs in the bottom, middle part and in the cover of the seam, and in the borehole 2944 it fully substitutes the coal.

The coal seam $v_{0}{ }^{3 \mathrm{H}}$ is splitted. This local splitting is exposed in the borehole 7005. It belongs to bifurcation and extends as far as $15.2 \mathrm{~km}^{2}$. The rock interlayer represented by argillite is $1.90 \mathrm{~m}$ in thickness.

The upper coal seam $v_{0}{ }^{\text {в }}$ occurs at a depth of 319.6-546.7 $\mathrm{m}$ below the limestone $\mathrm{V}_{1}$. Limestone predominate in its cover in the northern part of the 
Mykhailo Matrofailo, Mykola Korol

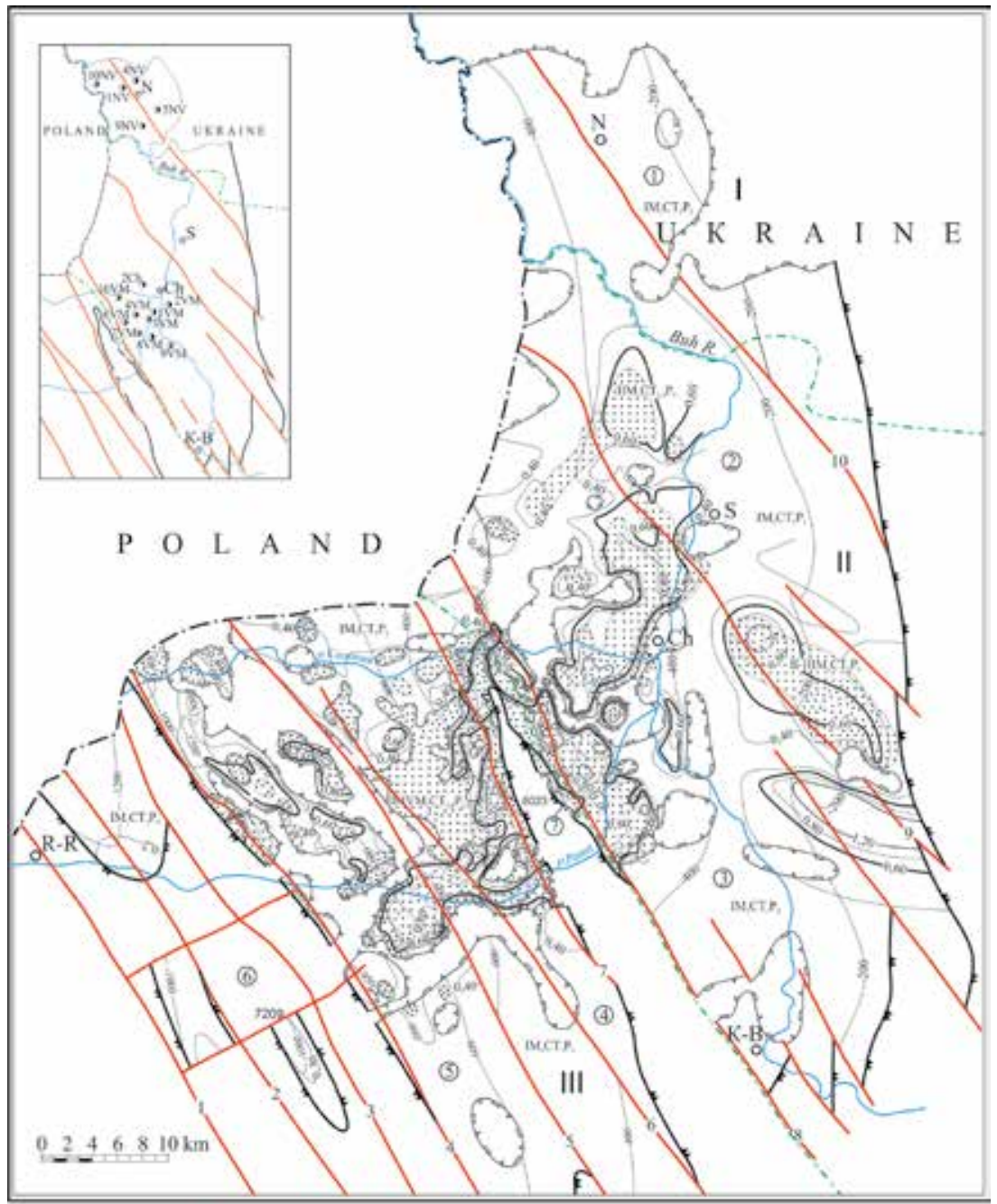

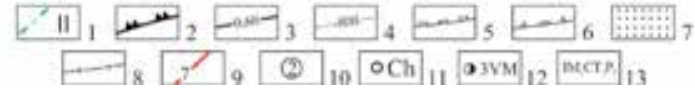

Figure 4. Map of morphology of coal seam $v_{6}$ of the Lviv-Volyn Coal Basin (authors Ihor Kostyk and Mykhailo Matrofailo) 
1 - boundaries of geological-industrial regions (I - Novovolynsk, II - Chervonohrad, III - South-Western); 2 - boundary of epigenetic washout of coal-bearing formation; 3 - isopaches of coal seam, $\mathrm{m} ; 4$ - isohipses of the coalbed foot, $\mathrm{m}$; 5 - contour of mainly synpeaty and early-epipeaty washouts and substitutions of coal seam; 6 - contour of synpeaty and epipeaty washouts and substitutions of coal seam; 7 - coal seam of composite structure (two or more coal units); 8 - line of coal seam splitting; 9 - tectonic dislocations with a break of continuity: 1 - Rava-Ruska fault, 2 - Krekhiv overthrust, 3 - Zashkiv fault, 4 - Nesteriv zone of overthrusts (Nesteriv overthrust), 5 - Butyn-Khlivchany zone of thrusts, 6 - Boyanets overthrust, 7 - Belz-Kulychkiv overtrust, 8 -Belz-Mylyatyn zone of overthrusts, 9 - Zabuzkiy and Sokal fault, 10 - Volyn fault; 10 - coal fields (1 - Volyn, 2 -Zabuzke, 3 - Mezhyrichenske, 4 - Tyagliv, 5 - Lyubelya), areas and plots (6-Byshkiv coal-bearing area, 7 - plot of Mezhyrichya-Western); 11 - populated area: R-R - Rava-Ruska, K-B - Kamyanka-Buska, Ch - Chervonohrad, S - Sokal, N - Novovolynsk; 12 - mine and its number (NV - Novovolynsk, Ch - Chervonohrad, VM - Velyki Mosty: No. 1 - "Velykomostivska", No. 2 - "Bendyuzka", No. 3 - "Mezhyrichanska ", No. 4 "Vidrodzhennya", No. 6 - "Lisova", No. 7 - "Zarichna", No. 8 - "Vizeiska", No. 9 - "Nadia", No. 10 - "Stepova"); 13 - alphabetical-digital index of the seam

area, in the south - argillite, rarely siltstone and sandstone, at the bottom in the east part argillite and in the west - siltstone. A sphere of its extension coincided with the lower seam. The thickness of the seam varies from 0.10 to $1.38 \mathrm{~m}$ (borehole 5484 ) and corresponds to three types of gradation (I - III). The seam with conditional thickness between 0.94 and $1.38 \mathrm{~m}$ extends over large areas of the Lyuboml plot. Further to the west, its thickness is very thin: from 0.10 to $0.15 \mathrm{~m}$ (borehole 4015,7005$)$. Change in the thickness is low $\left(\mathrm{M}_{1}\right)$. According to reserves classification, the seam belongs to relatively consistent. Its structure becomes changed from simple $\left(\mathrm{CT}_{1}\right)$, prevailing in the Lyuboml plot, to middle complexity and complex $\left(\mathrm{CT}_{2-3}\right)$ extended over this plot in some cases: with one rock interlayer borehole 5484, with two - borehole 5490. Rock intercalations are composed of coaly argillite and argillite $0.04-0.09 \mathrm{~m}$ thick, and in the borehole 2944 coaly argillite $0.20 \mathrm{~m}$ thick fully constitute coal.

The coal seam $v_{0}{ }^{3 в}$ is locally splitted too. Splitting is exposed in the borehole 4015 . It belongs to bifurcation and occupies the area of $7.9 \mathrm{~km}^{2}$. The thickness of the rock interlayer represented by siltstones and partly by sandstones reaches $1.20 \mathrm{~m}$. In both case local splittings are distributed in the tectonically most active central Lyuboml plot of the Kovel area. Their contours are oval and intersect the state border extending to the territory of the Lyublin basin of the neighbouring Poland. 


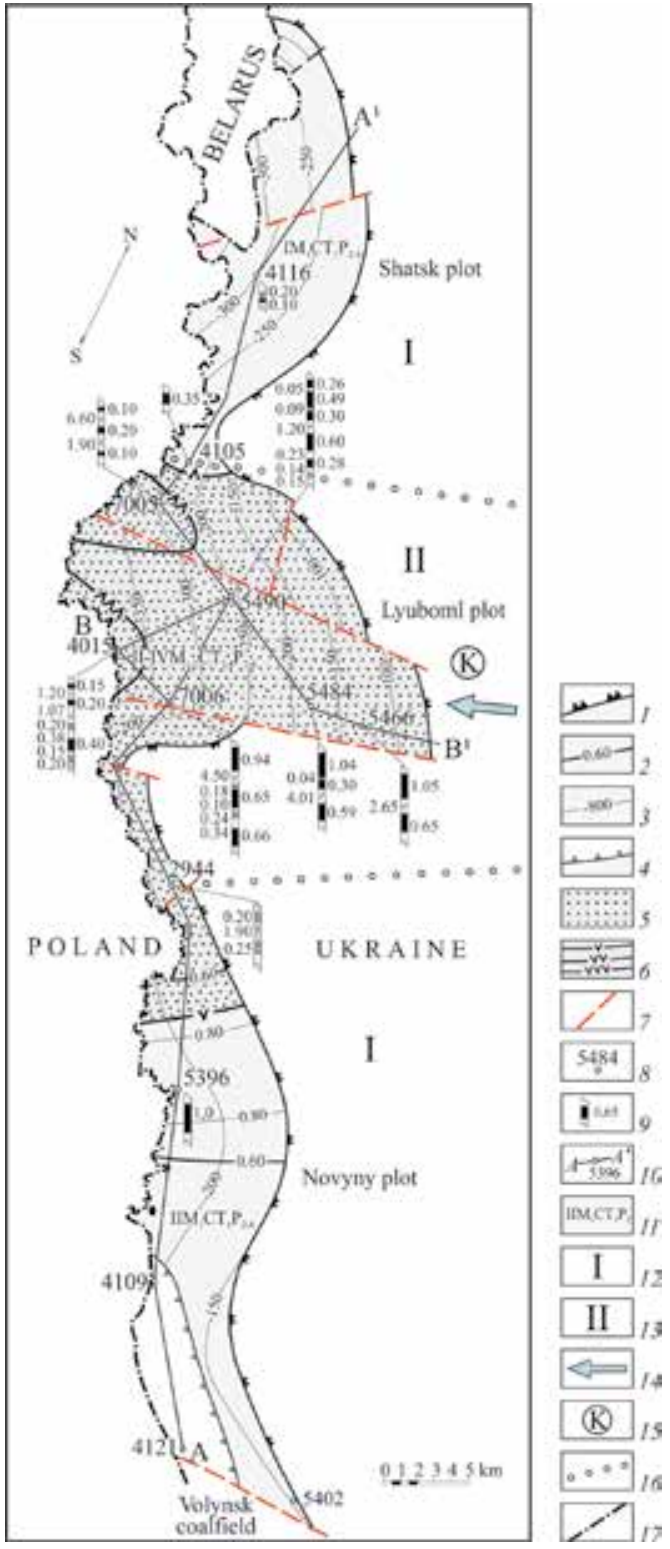

Figure 5. Map of morphology of coal seam $v_{0}{ }^{3}$ of the Kovel coal-bearing area of the Lviv-Volyn Coal Basin

1 - boundary of epigenetic washout of coal-bearing formation; 2 - isopaches of coal seam, $\mathrm{m} ; 3$ - isohypses of coalbed foot, $\mathrm{m} ; 4$ - contour of mainly epipeaty washouts of coal seam; 5 - coal seam of composite structure (two and more coal units); 6 - line of splitting of coal seam at different stratigraphic levels; 7 - tectonic dislocations with a break of continuity; 8 - borehole and its number; 9 - structure of seam and thickness of coal units and rock interlayers; 10 - location of detailed cross-sections; 11 - alphabetical index of coal seam; 12 - boggy seaside lowland; 13 - delta; 14 - directions of paleostreams; 15 - Kovel Carboniferous hydrographic system; 16 - boundary of paleogeographic zones; 17 - state frontier 


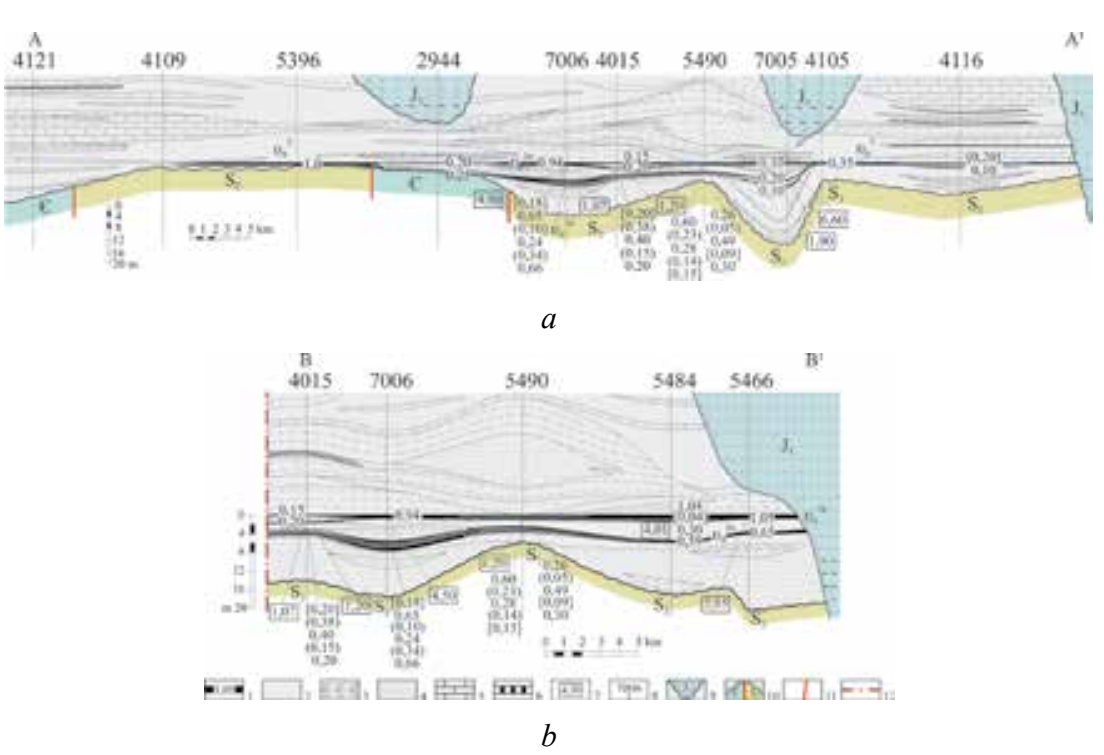

\section{Figure 6. Morphological sections of coal seam $v_{0}{ }^{3}$ along $\mathrm{A}-\mathrm{A}^{1}(a)$} and $B-B^{1}(b)$ (lines of section are indicated in Figure 5)

1 - coal seam and its thickness; 2 - argillite; 3 - siltstone; 4 - sandstone; 5 - limestone; 6 - coaly argillite; 7 - thickness of rock interlayer of splitting; 8 - bore well and its number; 9 - Jurassic washout of coal-bearing formation; 10 - washed surface of Cambrian and Silurian deposits underlying coal-bearing deposits; 11 - tectonic dislocations with a break of continuity; 12 - state frontier

On the whole, the coal seam $v_{0}{ }^{3}$ in the Kovel area is of composite structure and is splitted into two conditional coal seams $v_{0}{ }^{3 \mathrm{H}}$ and $v_{0}{ }^{3 \mathrm{~B}}$ reaching the maximum thickness for the Lyuboml plot. Genetic indication of its splitting are contained in that the thickness of overall compact part of coal seam up to its splitting is comparable with total thickness of coal units (in neighbouring boreholes) composing it in the zone of splitting, and complication of their structure and gradual increase in the thickness of the rock interlayer, that consists of argillite and sometimes of siltstone, occurs in the direction of the centre of the studied area. Its greatest thickness is equal to $6.60 \mathrm{~m}$ (borehole 7005). This is also characteristic of the change in the thickness of the whole coal mass reaching $25-30 \mathrm{~m}$ in the centre of the area and decreases in the northern and southern directions. The gradient of 
splitting in the meridian direction for different sections becomes changed from 0.16 to $0.45 \mathrm{~m} / \mathrm{km}$, on an average $0.28 \mathrm{~m} / \mathrm{km}$. The seam $v_{0}{ }^{3}$ is splitted from the north to the south and from the south to the north over the area of $202.7 \mathrm{~km}^{2}$. The contours of splitting stretch sublatitudinally forming a composite phasic three-time bifurcation. It should be noted-that fragments of its contours in the west of the area intersect the state border, and in the east they are destroyed by washing of the coal-bearing formation together with the whole carboniferous thickness.

Morphology of the coal seam $v_{0}{ }^{3}$ and its constituents was changed under the influence of interformational and epigenetic (formational) washout of carboniferous deposits. The fragment of interformational washout, belonging mainly to epipeaty washout of the coal seam, is located in the Novyny plot. It is caused by abrasion, because in its cover the limestone occurs. The contour of washout is directed beyond the limits of the area.

Washout of the coal-bearing thickness (epigenetic washout of the coal-bearing formation) in the territory of the Kovel area has decreased considerably the area of extension of coal seams, commercial coal presence and, mainly, has formed modern contours of their morphology that represent only a part of carboniferous deposits which occupied considerably larger territory before Post-Carboniferous washout. The modern configuration of the boundary of epigenetic washout is secondary one-denudational. It stretches submeridionally and occupies the whole Kovel area. Taking into consideration the relationship between the surface, the contour of washout and morphology of coal seams (their thickness, structure, extension of boundaries of splitting etc.) we can come to a conclusion that: destroyed at least the part of the seam together with the coal-bearing thickness is similar by volume to preserved one $\left(\mathrm{P}_{2-4}-25-50 \%\right.$ and more $)$.

Coal seam v $_{6}$. In the Volyn field which structurally is in the northern part of the Lviv-Volyn Basin situated within the limits of the Lviv Paleozoic deep, not in all areas $v_{6}$ is distributed (see Fig. 4). In the north and in the east of this field it is absent due to epipeaty washout, and in the rest of the area, where it is well-studied, there is no commercial value. It occurs at a depth of from 418 to $499 \mathrm{~m}$ in the thickness of siltstones and argillites with interlayers of sandstones, it has mainly one-unit, rarely two-unit structure (borehole 4317), thickness of $0.10-0.46 \mathrm{~m}$ and only boreholes 3903 and 4317 have fixed the thickness of 0.50 end $0.60 \mathrm{~m}$ correspondingly. Coaly 
argillites are developed here and there, and they occur in the cover of the coal seam (borehole 4326).

Within the limits of the Zabuhsky and Mezhyrichya fields, the seam is widely distributed and has a commercial value at most plots and mine fields. But it is not characteristic of stable thickness and structure in all areas. In the Zabuhsky field belonging to the Zabuhsky monocline, Sokal brachisyncline and the north-western edge of the Mezhyrichya syncline and is cut off from the Volyn field by relatively deep, 50-70 m, Jurassic washout of the coal-bearing deposits, the seam $v_{6}$ occurs at a depth of 508-687.5 m in the thickness of siltstones and argillites with interlayers of sandstone. Having working thickness ranging from 0.50 to $1.34 \mathrm{~m}$ and on an average is $0.76,0.88,0.62$ and $0.72 \mathrm{~m}$ correspondingly; it is distributed in the fields of Chervonohradska-1, 2, 5, 6 mines. But only in the field No. 2 the seam belongs to the group of persistent by the thickness, and in other fields it is unpersistent. Its structure becomes changed from one-unit to composite and very-composite (from two-three unit to multi-unit). The seam of two- and three-unit structure with the thickness of the lower coal unit of $0.36-1.23 \mathrm{~m}$, of the middle $-0.10-0.45$ (with three-unit structure), and of the upper $0.08-0.36 \mathrm{~m}$, rarely $0.46-0.68 \mathrm{~m}$ is prevailing. The thickness of rock interlayers that divide the coal seam and are composed mainly by argillites and coaly argillites usually is insufficient, and becomes changed from the first centimetres to $0.15 \mathrm{~m}$ and only in some cases it reaches $0.23-0.50 \mathrm{~m}$.

In the Mezhyrichya field belonging to the Mezhyrichya syncline separated by sloping uplift from the Sokal brachisyncline in the north-east (the Chervonohrad anticlinal zone), the seam $v_{6}$ occurs in the siltstone-sandstone thickness of rocks at a depth from 692 to $810 \mathrm{~m}$. It is of commercial value in the fields of "Mezhyrichanska" "Vidrodzhennya", "Lisova", "Zarichna", "Vizeiska" and "Stepova" mines where its thickness varies from 0.40 to $1.65 \mathrm{~m}$ with average values of 0.76 and $0.69,0.58,0.86,0.82$ and $0.77 \mathrm{~m}$ correspondingly. Based on the thickness, the seam belongs to the group of unpersistent, and only in the field of the "Zarichna" mine it is relatively persistent. In the eastern part of the deposit in the fields of the "Velykomostivska", "Bendyuzka", "Velykomostivska-5" and "Nadia" mines, the seam is washed-out partly, and in the rest fields - unworkable. Almost everywhere the seam is composed of two coal units divided by a thin rock interlayer reaching $0.05-0.10 \mathrm{~m}$. The basic thick unit is the lower set, whereas 
the upper unit is low and doesn't exceed $0.25 \mathrm{~m}$. The cover of the seam is composed mainly of argillites, sometimes of siltstones, the basement of siltstones. The composite structure of $v_{6}$ is characteristic of individual crossings of the seams in the western part of the field of the "Lisova" mine where within limits of the Zhuzhelyany overthrust it is splitted into two coal units. The area of splitting stretches along this dislocation.

In the Mezhyrichya field, the seam $v_{6}$ belongs to the group of thin according to the thickness, and has a low changeability. Increased changeability is observed only in the board parts of synpeathy and early epipeaty washouts the area of which is insufficient on the whole within the limits of the field. Thus, its morphostructure is composite and has a zonal character formed by certain seam-forming conditions.

In the Mezhyrichya-Western area ajoining with the fields of "Lisova", "Zarichna" and "Stepova" mines of the Mezhyrichya deposit, the coal seam $v_{6}$ is widely distributed, and it is absent only in the near-axial part of the Kulychkiv uplift where the upper part of carboniferous deposits of the basin is cut off by erosion, including the seam $v_{6}$ and the underlying coal seam $v_{5}{ }_{5}$. The seam $v_{6}$ occurs in the thickness of argillites, siltstones with interlayers of sandstones and rarely limestones at a depth of from $468-500 \mathrm{~m}$ in the region of the Kulychkiv uplift to $700-873 \mathrm{~m}$ in the north, the south-east and the south-west of this area. According to data of 107 crossings, in the greater part of this area the thickness of the seam is $0.50-2.0 \mathrm{~m}$, and on an average $-0.84 \mathrm{~m}$. It belongs mainly to the group of thin and is relatively persistent. The seam keeps the commercial value also within the limits of the lying side of the zone of Vanevsky and Zhuzhelyansky overthrusts with the amplitude of about $162 \mathrm{~m}$. On the whole, the change in its thickness has a zonal, wave-like character. Zones with low thickness become changed are substituted for plots of grater area with conditional thickness. At greater part of the Mezhyrichya-Western plot it is characterized by low and average changeability of the thickness, and by composite and very composite onenear the Belz-Kulychkiv and Zhuzhelyansky overthrusts.

In the Mezhyrichya-Western plot, the structure of seam changes from the simple one-unit to composite and very composite two- and three-unit and more. Incidentally, the seam of two- and three-unit structure predominates. On the whole, the structure of the seam from the plot as well as changeability of its thickness has a marked zonal character: local fields of 
simple, composite and very composite structure are expressed on the background of the field of two- and three-unit structure that predominates. The most verified structure of the seam is observed on the eastern edge of the Kulychkiv anticlinal uplift and in the border line of active mines of the Chervonohrad coal industrial region. Here at most crossings of the seams it has very composite multi-unit layered structure which often is substituted for the two- and three-unit structure, and sometimes - for simple one-unit.

In the Tyagliv field, the boundaries of which are Poland state border in the north, the Butyn-Khlivchany zone of thrusts in the west, the Belz-Mylyatyn zone of thrusts in the east, in the south - the working contour of the coal seam $n_{7}{ }^{\text {म }}\left(n_{7}\right)$, the seam $v_{6}$ with commercial thickness is distributed in the south part, in the field of the Tyaglivska-3 mine. In the rest area (in the field of mines No. 1 and 2) it is splitted into two, in some cases into three coal units due to which the thickness of its units decreases considerably, and its commercial value is lost. The seam occurs in the thick series of aleurolites (44.8\%), argillites (35.4\%) and sandstones (14.1\%) with the few interlayers of limestones (up to 5\%) at a depth of from 697.8 to $1015.6 \mathrm{~m}$ that averages $837.4 \mathrm{~m}$. With the workable thickness it occurs at a depth of from 815 to $850 \mathrm{~m}$. It is characterized by simple and composite mainly two-unit structure. The upper coal unit is thin $-0.06-0.16 \mathrm{~m}$. The rock interlayer is composed mainly of argillite about $0.15 \mathrm{~m}$ thick. Total thickness of the seam found more frequently reaches $0.70-1.00 \mathrm{~m}$, in the field of the Tyaglivska-3 $-0.50-1.44 \mathrm{~m}$ with average value of $0.73 \mathrm{~m}$. In its cover there are argillites, rarely siltstones, in the bottom - siltstones, argillites, sometimes sandstones.

In the fields of mines No. 1 and 2 the seam is inpersistent and belongs to the group of very thin, in the south and the south-east of the field of the mine No. 3 - relatively persistent and belongs to the group of thin, and in some plots - to the middle group. By changeability of thickness it is of low and medium complexity.

In the Lyubelya field located 5.0-7.7 km west of the Tyagliv field and is separated from it by a narrow Butyn anticlinal zone with a domed part complicated by Butyn-Khlivchany thrust zone, of the seam $v_{6}$ is distributed unevenly in all minefields due to considerable affection by synpeaty and epipeaty washouts and substitutions reaching $57.7 \%$ of total area of the deposit. It is located in the thickness of terrigenous rocks composed of 
siltstones (51.0\%), argillites (29.3\%) and sandstones (15\%) with interlayers of limestones (3.8\%). A depth of occurrence varies from $641.7 \mathrm{~m}$ in the east and the south-east to $1517.8 \mathrm{~m}$ in the north-west of the deposit. By thickness ranging from 0.38 to $1.24 \mathrm{~m}$ and reaching $0.66 \mathrm{~m}$ on an average, the seam is inpersistent and belongs to thin and very thin groups. Its least thickness is observed mainly in the fields of the Lyubelska No. 2 and 5 mines. At a greater part of the Lyubelya field it has a low and average thickness, and only in some plots of the mines Lyubelska No. 2 and 3 and in the central part of the Lyubelska-1 mine - a strong one.

Morphology of the seam $v_{6}$ of the field is composite, and in the fields of the Lyubelska No. 3 and 4 mines, in the western and the southern part of the field of the mine No. 1 it is mainly of simple one-unit structure, in the field of the mine No. 2 and in the southern half of the field of the mine No. 3 it has one-unit, two-unit and sometimes three-unit structure, with prevailing of the one-unit structure. In the central part of the field of the Lyubelska-1 mine the seam has two- and three-unit structure. The thickness of rock interlayers varies from 0.02 to $0.38 \mathrm{~m}$. They are represented mainly by argillites and siltstones, sometimes by coaly argillites located in the cover and in the foot of the seam. The cover of the seam usually is composed of argillites and sometimes of siltstones, and the foot - of siltstones, sometimes of sandstones.

The structure of the coal seam $v_{6}$ in the territory of LVB is complicated by

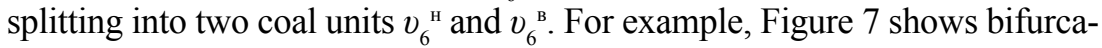
tion of the seam in the Tyagliv field of the South-Western region of the basin in detail that is the basic type of splitting. That's quite normal that almost all fields of decomposition belong to the Belz-Mylyatyn thrust zone. Incidentally, at most seam crossings the lower unit is the basic one, its thickness varies from $0.12-0.28$ to $0.64-1.18 \mathrm{~m}$. Rock interlayers, separating splitted units, are composed of argillites, sometimes of siltstones and sandstones. Their thickness varies within wide bounds from $0.52-5.60$ to $6.40-14.60 \mathrm{~m}$.

It should be noted that a modern configuration of the distribution contour of carboniferous deposits of LVB is a result of revealing the Asturian tectonic movements and later deep-seated pre-Upper Jurassic and pre-Upper Cretaceous erosional and abrasion truncations [20]. The LVB and especially the Kovel coal-bearing area compose the most uplifted closed peripheral part of the great Lviv-Lublin depression where Post-Carboniferous denudation processes occurred especially intensively. This has caused the 
absence in the basinal stratigraphical section of Carboniferous of deposits younger than Late-Bashkirian (Westphalian A) in its central part and Late Serpukhovian (Post-Ivanychi) ones in the territory of the Kovel area.

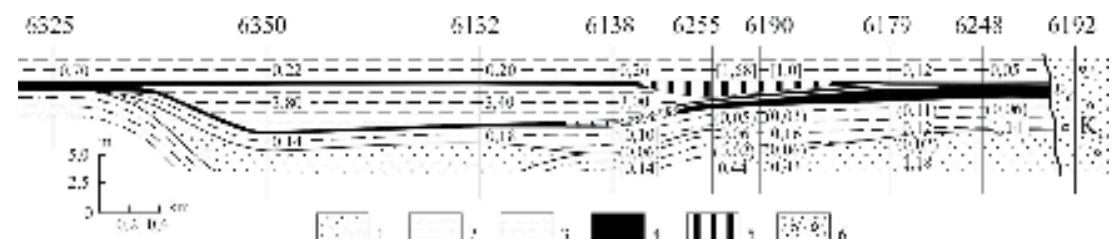

Figure 7. Splitting (bifurcation) of coal seam $v_{6}$ in the are of the Tyagliv field of the South-Western coal-bearing region

1 - sandstone; 2 - siltstone; 3 - argillite; 4 - coal; 5 - coaly argillite; 6 -deposits of Cretaceous system

\section{Formation conditions of coal seams. Types of peat accumulation}

Commercial coal seams of the lower subformation of the Lviv-Volyn Basin were formed in different conditions. In the north of the basin, within the limits of the Kovel coal-bearing area, the commercial coal seam $v_{0}{ }^{3}$ is located in the lower part of subformation, very close to the basement represented by pre-coal deposits of Early Paleozoic. Considerable change in its morphology was caused by specific conditions of coal-forming. Before the beginning of the formation of coal-bearing deposits, the studied area was a marshy coastal lowgrounds with the rather divided erosional-tectonic relief. Its reconstruction according to known methods [9; 14; 22] using the basement of the coal seam $v_{0}{ }^{3 \mathrm{H}}$ as a conventional (zero) horizon has shown that exceeding of pre-Carboniferous paleorelief is $20 \mathrm{~m}$ and more (Figure 8). In the central part of the territory, there existed a large (over $20 \mathrm{~km}$ wide) latitudinal valley-like reduction where channel and flood-plain alluvium was deposited. Increase in the thickness of alluvium in the western direction as well as results of paleopotamic analysis of the coal-bearing deposits of LVB [16] indicate the probable location of the upper reaches of paleoriver in the east - in the region of the Ukrainian Shield. Paleomorphological reconstructions, conducted by us, dave shown that during the period of the formation of the coal seams $v_{0}{ }^{3 \mathrm{H}}$ and $v_{0}{ }^{3 \mathrm{~B}}$ and also of limestone $\mathrm{V}_{1}$ the valley-like reduction underwent the greatest inherited subsidence in comparison with 


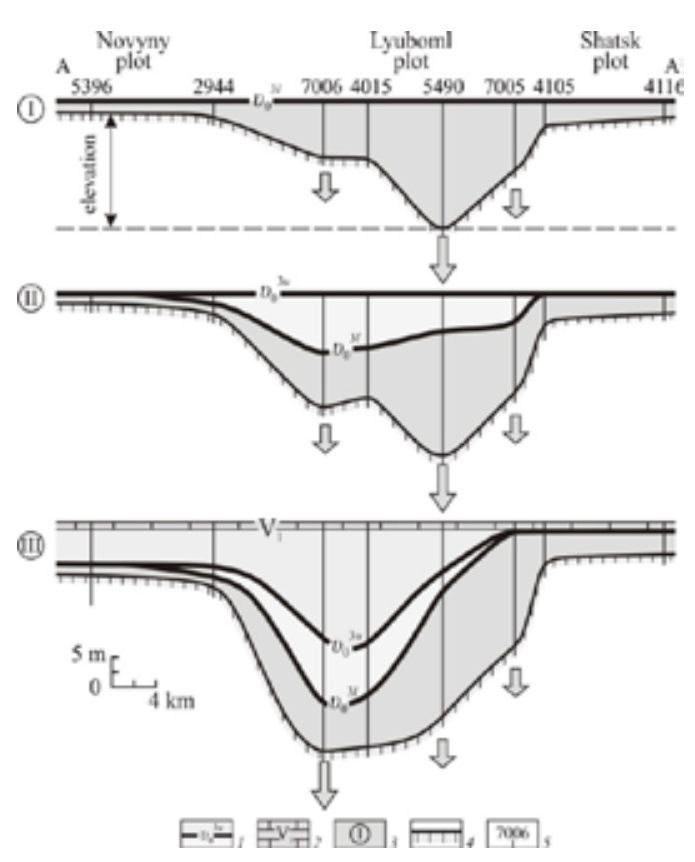

Figure 8. Reconstruction of formation stages of accumulative-tectonic splitting (bifurcation) of coal seam $v_{0}{ }^{3}$ and surface of pre-Carboniferous deposits along the line $A-A^{1}$ in the Kovel area of the

Lviv-Volyn Basin

1 - coal seam and its synonymics; 2 - seam of limestone and its synonymics; 3 - formation stages of splitting: I - formation of lower coal seam, basement of splitting; II - formation of rock interlayer of splitting and upper coal seam; III - completion of splitting formation and its overburdening with rock deposits and limestone $\mathrm{V}_{1} ; 4$ - surface of pre-Carboniferous deposits; 5 - bore well its number

neighbouring (northern and southern) more uplifted areas. This has shown itself not only in the increased thickness of alluvium and coal-bearing deposits, underlying limestone $\mathrm{V}_{1}$ on the whole but in accumulative-tectonic decomposition of the coal seam $v_{0}{ }^{3}$ into two seam in the field of paleovalley. Mother substance of the seam $v_{0}{ }^{3}$ was accumulated in the paleopeat bogs located both within the great latitudinal valley-like subsidence and in the northern and in the northern and in the southern intervalley spaces. The most favourable conditions for the formation of the paleopeat bogs were found on the slopes of paleovalleys; to a lesser extent - in its central part which was characterized by a high level of standing water, increased hydrodynamics, bringing of a considerable amount of terrigenous material into the peat bogs that caused a composite structure of the coal seams and their increased ash content. Low irrigating and intensive decomposition of a vegetable mass in aerobic conditions didn't promote forming of thick peat bogs in the uplifted areas of intervalley space. 
Specific conditions of the peat accumulation in the paleovalley have predetermined a peculiar petrophysical composition of coal. In contradistinction to mainly semibright durite-clarain coal of the principal territory of LVB, indicated coal seams are composed of dull, semidull clarain-durite coal. Their main component is a group of vitrinite (on an average $-49.6 \%$ ). Of macerals, kolinite (33.1\%) and telinite (14.6\%) are the most widespread. The composition of macerals of the group of semivitrinite averages $4.0 \%$. Of wide development (26.2\%) are macerals of the group of inertinite: semifusinite, fusinite, micrinite, inertodetrinite. Their concentration is correspondingly equal to: 9.4, 6.6, 5.1 and 5.1\%. In coal the group of leptynite (27.7\%) also is well-developed and mainly is represented by sporinite the concentration of which reaches $25.9 \%$ in some samples. Thus, in the coal of seams $v_{0}{ }^{3 \mathrm{H}}$ and $v_{0}{ }^{3 \mathrm{~B}}$ not a group of microelements reaches $50 \%$. According to the classification of the All-Russia Research Geological Institute [4], they are typical mixthohumolites in contradistinction to helitholites composing the basic coal mass of LVB. Peculiarity of the coal from the seams $v_{0}{ }^{3 \mathrm{H}}$ and $v_{0}{ }^{3 \mathrm{~B}}$ of the Kovel area also is that kolinite predominates over telinite in the group of vitrinite to a great extent, the distribution appoximately equal quantity of such macerals as fusinite, semifusinite and micrinite in the group of inertinite; moreover, predominance of macrospores is observed in the group of leptynite.

There are notions [4] of that initial organic substance of coal of the same petrophysical composition was accumulated in well-drained peat bogs in the conditions of constant access of oxygen, microbe activity and carrying out of a greater part of humic acids. There occurred intensive decomposition of lignin-cellulose substance, and due to its washing away by the flowing water - enrichment of organic mass with the most stable to destruction microcomponents of the group of leptynite (spores, cuticle and other).

Such a dependence between the coal presence and peculiarities of pre-coalbearing paleorelief within the northern continuation of LVB was revealed for the first time. It shows itself in bifurcation of the coal seam and in complexity of its structure in the direction of the valley-like lowering. Thus, a new type of the peat accumulation was established in LVB characteristic of the coal-bearing formation of ancient platforms distributed immediatly on the erosional surface of underlying formations [6]. Formations of the basin near Moscow, Donets and other coal basins belong to such kind [7; 12;13]. 
Similarity of the formation conditions of the Visean coal-bearing deposits of the Moscow Basin and the lower coal-bearing subfomation of the northern continuation of LVB becomes more obvious with consideration of almost the same substance composition of coal for both regions.

Latitudinal stretching of paleovalleys, their tracing up to the Poland state frontier and data of drilling of the Savin IG 1 borehole, that has drilled the seam $2.0 \mathrm{~m}$ thick located almost directly on the denuded surface of Late Paleozoic [11] confirm that indicated peculiarities of the formation of the lovers coal-bearing subformation of the northern continuation of LVB existed also in the frontier territory of the Lublin Basin [20].

Other conditions existed in the period of the formation of the coal seam $v_{6}$, to that indicate cited peculiarities of its morphology. It is located in the thickness of terrigenous rocks between limestones $\mathrm{V}_{6}$ and $\mathrm{N}_{1}$ of the lower marshy-marine coal-bearing subformation that on the whore is characterized by the most expressed paralic type of coal-forming and occurs in the lagoonal-marine sedimentary cycle of the first order [19]. Common regressive character of sedimentation in the period of forming subformation led to the sea deviation in the south-western direction, in consequence continental environments of sedimentation were gradually distributed, displacing marine ones. Thus, there arouse favourable conditions for the formation of the peat bogs. In the time of the greatest regression and the formation of the coal seam $v_{6}$ the processes of accumulation of initial organic substance occurred over the whole territory of the basin, and the shore line of the sea was displaced to the south-west beyond the studied territory (to the southwest of the Byshkiv coal-bearing area).

In the period of the formation of the seam $v_{6}$ the locality represented a subaerial slightly dipping to the south-west deltal plain intersected by numerous very branched river beds, channels, sources of which were situated in the region of the Ukrainian Shield (Figure 9). Widely distributed within subaerial delta the river system had a great influence on the formation conditions of the seam $v_{6}$. At that time in the territory of LVB, the Dubno and Horokhiv-Rivne hydrographic systems existed that is confirmed by the widely distributed siltstone-sandstone deposits of accumulative bodies (Figure 10).

Widly developped river system considerably influenced the formation condition of the seam. The formation of paleopeat bogs occurred mainly in uplifted plots located between water streams which are characterized by un- 


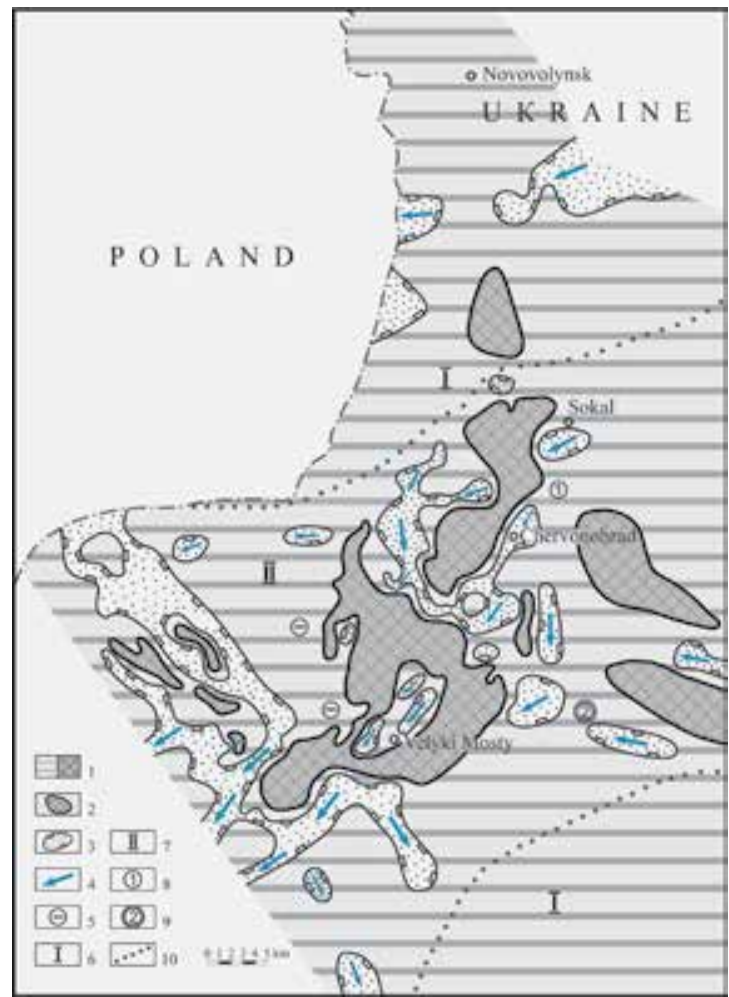

Figure 9. Paleogeographic map of the time of coalbed $v_{6}$ formation

1 - peat bogs; 2 - plots of the most favourable conditions for peat accumulation; 3 - area where paleopeats are absent; 4 - directions of water flows; 5 - areas of the most intensive subsidence of the locality; 6 - flooded coastal lowland; 7 - delta; 8-9-paleohydrogtaphic systems: 8 -Horokhiv-Rivne, 9 - Dubno; 10 - boundaries of paleohydrogtaphic zones

favourable conditions for the plant life. The explanation of this serve waved outlines of the peat massifs, their size and orientation of the boundaries. Within these bounds, synpeaty and early-epipeaty substitution and washouts of paleopeat bogs were widely developed in connection with that the formation of the seam $v_{6}$ at such areas didn't occur. The smallest channels, within which accumulation of the plant material was absent, existed inside the peat massifs. From the position of the method of actualism, similar 


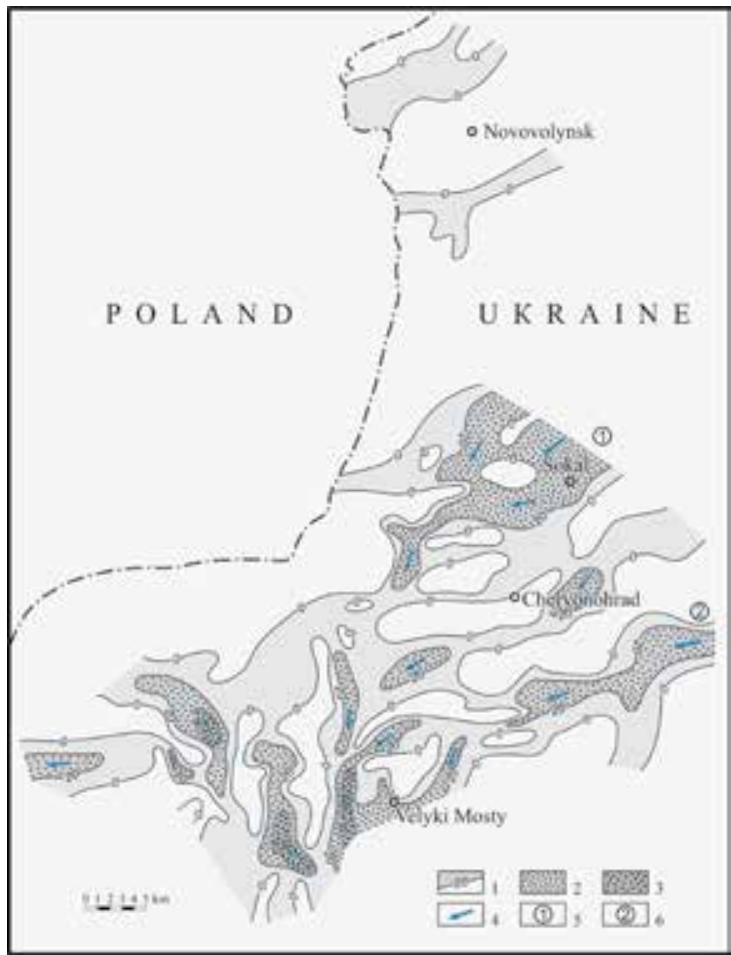

Figure 10. Distribution of siltstone-sandstone deposits of accumulative bodies of main water currents in the period of formation of regressive part of lithocycle $V_{6}-v_{6}$

1 - isolines of concentration of siltstone-sandstone deposits of accumulative forms, \%; $2-3$ - contents of sandstones and siltstones, $\%: 2-20-40,3$ - over 40; 4 - directions of currents of main water flows; 5 and 6 - paleohydrographic systems Horokhiv-Rivne and Dubno

conditions are observed in the peat bogs from the region of the delta of the Mississippi River (Figure 11) [5].

Location of the delta quite close to the sea also is a negative factor for the formation of the seam $v_{6}$. As a result of the sea transgression, water penetrated depressed plots of the relief. There the formation of coastal lakes, salted bogs with a high level of water standing, preventing the plant growth, occurred. 


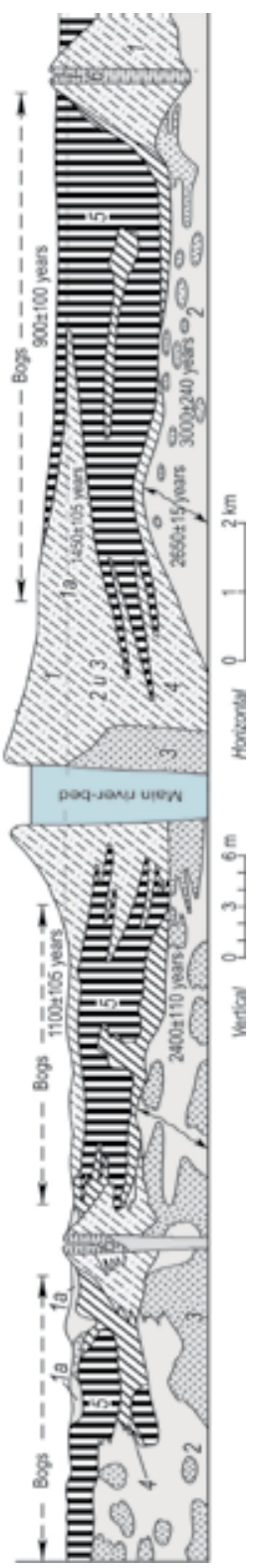

The most favourable conditions for the peat accumulation existed in the central part of the peat massifs remoted from the river channels. Great peat bogs of considerable thickness were formed in the mouth part of the subaerial delta in the inner part of the Lviv tectonic deep (farther south of Chervonohrad).

In comparison with the outer zone of the deep which is situated father north-east, it was characterized by greater mobility of the basement and more intensive subsidence of the locality that promoted forming of the peat bogs of increased thickness. Consedimentary tectonic movements as well as frequent fluctuations of the level and dynamics of ground water have caused numerous splittings of the seam $v_{6}$ and formation of the rock layers in it. Apart from positive effect of the tectonic factor which determined subsidence of the locality and accumulation of great masses of organic substance, the formation of the peat bogs of increased thickness was conduced by the river beds, channels through which a considerable amount of terrigenous material passed to the area of sedimentation and a compensation regime of sedimentation was kept.

In the far south-west of the basin within the mouth part of the alluvial-deltaic plain located near the sea, the conditions for the formation of the paleopeat bogs became less favourable due to limited demension of uplifted plots which became boggy, increase in the level of water standing in the peat bogs, decrease in duration of the peat accumula- 
tion. The distribution of the plots with workable thickness of the seam has an island character. The next subsidence of the locality has led to transgression of the sea, settling of lagoonal-lacustrine environments, stopping of the formation of the seam $v_{6}$ over the whole territory of the basin.

\section{Conclusions}

Investigations of the coal presence, studies of the peculiarities of morphology and substantiation of the commercial value of the coal seams of deep horizons are urgent from the point of view of the problem of possible prolongation of the period of exploitation of active mines and further development of the Lviv-Volyn Basin.

Within the bounds of deep horizons in deposits of the lower coal-bearing subformation, the coal seams $v_{0}{ }^{3}$ and $v_{6}$ are considered to be basic and are of the greatest commercial significance, and are widely distributed with working thickness. In the Kovel perspective area and the central part of the basin $-v_{0}{ }^{3}$ and $v_{6}-$ in the Zabugske and Mezhyrichya fields of the Chervonohrad coal industrial region.

Dependence between peculiarities of the pre-Carboniferous paleorelief and the formation of the coal-bearing thickness of the Kovel area was marked for the first time. Conducted paleogeomorphological reconstructions have revealed the existence of the latitudinal (over $20 \mathrm{~km}$ wide) valley-like lowering in its central part that has undergone the most inherited subsidence and has led to the increase in the thickness of the coal-bearing deposits underlying limestone $\mathrm{V}_{1}$, and to accumulative-tectonic splitting of the coal seam $v_{0}{ }^{3}$ into two conditional coal seams $v_{0}{ }^{3 \mathrm{H}}$ and $v_{0}{ }^{3 \mathrm{~B}}$, that is to say, to composite staged bifurcation. Thus, a new type of the peat accumulation was established in the Lviv-Volyn Basin characteristic of the platform carboniferous coal-bearing formations located directly on the erosional surface of different-age formations underlying them that needs of a special approach to exploring and prospecting.

The Serpukhovian coal seam $v_{6}$ was formed within the bounds of the subaerial deltaic plain where the most favourable conditions for the peat accumulation were found in the mouth parts of delta located in intrachannel space among coarse paleohydrographical system as well as in the inner part of the Lviv tectonic deep which is characterized by more intensive subsidence of the location and widly developed water flows. 
In the area of the basin, the most composite morphostructure of the coal seam $v_{6}$ is characteristic of the South-Western coal-bearing region, especially of the Tyagliv and Lyubelya fields and the plot of Mezhyrichya-Western. Exactly in that region it is splitted into two coal units $v_{6}{ }^{\mathrm{H}}$ and $v_{6}{ }^{\mathrm{B}}$. Especially great fields of splitting were distinguished in the south of the Tyagliv deposit and in the north-west of the plot of Mezhrichya-Western that testifies to the most unstable conditions of its formation in this part of the basin.

On the basis of detailed investigations of the peculiarities of formation and studies of the morphology of the coal seam $v_{6}$ of the deep horizons, a deltaic type of the peat accumulation was determined for the first time.

Cited material and conducted paleoreconstructions verify and supplement existing notions of carboniferous coal accumulation in the south-west of the East European Platform, and in particular of insufficiently studied deltaic type of the peat accumulation. Regarded in applied aspect, they are important in solving practical tasks connected with prognostic assessment of the commercial coal presence in the deep horizons of the Lviv-Volyn Basin.

\section{References:}

1. Bartoshinskaya E.S., Byk S.I., Muromtseva A.A. i dr. (1983). Uglenosnye formatsii karbona yugo-zapadnoy okrainy Vostochno-Evropeyskoy platformy [Carboniferous coal-bearing formations of the south-western margin of the East European platform]. Kiev: Naukova Dumka. (in Russian)

2. Biryulev A.E., Biryuleva L.V. (1974). Bazal'nye otlozheniya srednevizeyskogo pod"yarusa L'vovsko-Volynskoy vpadiny [Basal deposits of the Middle Visian sub-layer of the Lviv-Volyn basin]. Sovetskaya Geologiya, no. 9, pp. 141-143.

3. Derzhavna gheologhichna karta Ukrajiny masshtabu 1:200000, arkushi M-34-XVIII (Rava-Rusjka), M-35-XIII (Chervonoghrad), M-35-XIX (Ljviv) (2004) [State Geological map of Ukraine at a scale of 1:200000, sheets M-34XVIII (Rava-Ruska), M-35-XVIII (Chervonohrad), M-35-XIX (Lviv)]. Kyiv: Ministerstvo ekologhiji ta pryrodnykh resursiv Ukrajiny, Derzhavnv gheologhichna sluzhba, NAK "Nadra Ukrajiny", DP "Zakhidukrgheologhija”, Ljvivsjka GhRE. (in Ukrainian)

4. Ginzburg A.I., Korzhenevskaya A.S., Volkova I.B. i dr. (1975). Petrograficheskie tipy ugley SSSR [Petrographic types of coal of the USSR]. Moskva: Nedra. (in Russian)

5. Gradzinskiy R., Kostetskaya A., Radomskiy A. Unrug R. (1980, Per. izd. PNR, 1976). Sedimentologiya: Per. s pol'sk. [Sedimentology: Transl. from Polish]. Moskva: Nedra. (in Russian) 
6. Ivanov G.A. (1967). Uglenosnye formatsii [Carbonaceous formations]. Leningrad: Nauka. (in Russian)

7. Korzhenevskaya A.S., Shul'ga V.F., Vinogradov B.G. i dr. (1962). Litologicheskaya kharakteristika vizeyskoy uglenosnoy tolshchi [Lithological characteristics of the Visean coal-bearing strata]. Geologiya mestorozhdeniy uglya $i$ goryuchikh slantsev SSSR [Geology of coal and oil shale deposits of the USSR]. Moskva: Gosgeoltekhizdat, vol. 2, pp. 77-114. (in Russian)

8. Kostyk I.O., Matrofajlo M.M., Sokorenko S.S. (2007). Perspektyvy promyslovoji vughlenosnosti nyzhnjoji chastyny kam'janovughiljnykh vidkladiv Ljvivsjko-Volynsjkogho basejnu [Prospects of commercial coal-bearing potential of the lower part of coal deposits of the Lviv-Volyn Basin]. Gheologhija i gheokhimija ghorjuchykh kopalyn, no. 1, pp. 27-44.

9. Lomashov I.P. (1958). O rel'efe izvestnyakovogo fundamenta v Podmoskovnom basseyne [On the relief of the limestone foundation in the Moscow region Basin]. Izvestiya Akademii Nauk SSSR. Seriya geologicheskaya, no. 3, pp. 93-100.

10. Matrofajlo M.M. (1991). Morfostruktura vughiljnogho plasta $v_{6}$ serpukhovsjkykh vidkladiv Chervonoghradsjkogho gheologho-promyslovogho rajonu Ljvivsjko-Volynsjkogho basejnu [Morphostructure of the coal seam $v_{6}$ of Serpukhovian deposits of the Chervonohrad geological-industrial district of the Lviv-Volyn basin]. Dopovidi Akademiji Nauk URSR, no. 2, pp. 67-71.

11. Musial L., Tabor M. (1988). Stratygrafia karbonu na podstawie makrofauny [Carboniferous stratigraphy based on macrofauna]. Karbon Lubelskiego Zaglębia Weglowego [Carboniferous of the Lublin Coal Basin]. Warszawa: Prace Instytutu Geologicznego, vol. 122, pp. 88-112. (in Polish)

12. Naghirnyj V.M. (1977). Paleogheoghrafichni umovy utvorennja kajnozojsjkykh burovughiljnykh pokladiv Ukrajiny [Paleogeographic conditions of formation of Cenozoic brown coal deposits of Ukraine]. Kiev: Naukova Dumka. (in Ukrainian)

13. Radzivill A.Ia., Guridov S.A., Samarin M.A. i dr. (1987). Dneprovskiy burougol'nyy basseyn [Dnipro brown coal basin]. Kiev: Naukova Dumka. (in Russian)

14. Shul'ga V.F. (1962). O fatsial'nom issledovanii uglenosnykh otlozheniy yuzhnogo kryla Podmoskovnogo basseyna [On the facies study of coal-bearing sediments of the southern wing of the Moscow region basin]. Izvestiya Akademii Nauk SSSR. Seriya geologicheskaya, no. 6, pp. 84-94.

15. Shul'ga V.F. (1981). Nizhnekarbonovaya uglenosnaya formatsiya Donetskogo basseyna [Lower Carboniferous coal-bearing formation of the Donets basin]. Moskva: Nauka. (in Russian)

16. Shul'ga V.F., Znamenskaia T.A. (1995). Karbonovye reki L'vovskoVolynskogo basseyna i ikh svyaz' s tektonikoy [Carboniferous rivers of the LvovVolyn basin and their relationship with tectonics]. Geologicheskiy zhurnal, no. 2, pp. 36-40.

17. Shulga V., Byk S., Dudok I. (2008). Coal-Bearing formation of the LvivVolyn basin. Field Trip Guide. (7-th European Coal Conf., Lviv, Ukraine, August 
26-29, 2008). Lviv: Institute of Geology and Geochemistry of Combustible Minerals of National Academy of Sciences of Ukraine, $60 \mathrm{p}$.

18. Shul'ga V.F., Matrofaylo M.N., Kostik I.E., Korol' N.D. (2010). Izuchenie morfologii ugol'nykh plastov v Ukraine. Sovremennoe sostoyanie. Napravleniya dal'neyshego razvitiya [Studying the morphology of coal seams in Ukraine. The current state. Directions for further development]. Zbirnyk naukovykh pracj Instytutu gheologhichnykh nauk NAN Ukrajiny, vol. 11, pp. 350-358.

19. Shul'ga V.F., Lelik B.I., Garun V.I. i dr. (1992). Atlas litogeneticheskikh tipov $i$ usloviya obrazovaniya uglenosnykh otlozheniy L'vovsko-Volynskogo basseyna [Atlas of lithogenetic types and formation conditions of coal-bearing deposits of the Lviv-Volyn Basin]. Kiev: Naukova Dumka. (in Russian)

20. Shul'ga V.F., Zdanovski A., Zaytseva L.B. i dr. (2007). Korrelyatsiya karbonovykh uglenosnykh formatsiy Lvovsko-Volynskogo i Lyublinskogo basseynov [Corelation of the Carboniferous coal-bearing formations of the Lviv-Volyn and Lublin basins]. Kiev: Varta. (in Russian)

21. Struev M.I., Isakov V.I., Shpakova V.B. i dr. (1984). L'vovsko-Volynskiy kamennougol'nyy basseyn. Geologo-promyshlennyy ocherk [Lviv-Volyn coal basin. Geological and industrial essay]. Kiev: Naukova Dumka. (in Russian)

22. Vasil'ev P.V. (1950). Paleogeograficheskie usloviya formirovaniya uglenosnykhotlozheniynizhnegokarbonazapadnogosklona Urala [Paleogeographic conditions for the formation of carbonaceous deposits of the Lower Carboniferous of the western slope of the Urals]. Moskva, Leningrad: Ugletekhizdat. (in Russian)

23. Vlasov B.I. (1990). Volynskoe paleozoyskoe podnyatie [Volyn Paleozoic uplift]. Geotektonika Volyno-Podolii [Geotectonics of Volyn-Podolia]. Kiev: Naukova Dumka, pp. 178-180. (in Russian)

24. Znamenskaya T.A., Chebanenko I.I. (1985). Blokovaya tektonika VolynoPodolii [Block tectonics of Volyn-Podolia]. Kiev: Naukova dumka. (in Russian) 